\title{
Antibiotic Sensitivity Pattern of the Isolated of Urinary Pathogens at Dhaka National Medical College \& Hospital
}

\author{
Md.Badrul Islam ${ }^{1}$, Munir Hasan ${ }^{2}$ \\ 1Assistant Professor, Department of Microbiology, Dhaka National Medical College, 2Professor and Head, \\ Department of Microbiology, Dhaka National Medical College.
}

\begin{abstract}
Urinary tract infection is the most common infection causing illness in children and adults. This study was aimed to identify the uropathogens and their antibiotic sensitivity pattern. This study was done in Microbiology Department at Dhaka National Medical College \& Hospital, Dhaka, during January, 2010 to December, 2010. A total of 1874 samples of urine were collected from suspected cases of urinary tract infections, from Dhaka National Medical College \& Hospital. Among them, 290 (15.48\%) showed significant bacterial growth. The most common uropathogens isolated were E.coli 229 (78.97\%), Staph. saphrophyticus 15 (5.18\%), Coliform 12 (4.13\%), Klebsiella spp. 10 (3.44\%), Enteococous $10(3.44 \%)$, Staph. aureus 05 (1.72\%), Streptococcus spp. 05 $(1.72 \%)$ and Pseudomonas spp. $04(1.38 \%)$. E.coli is the most common urupathogen and showed sensitivity pattern to Imipenem 84.28\%, Amikacin 83.41\%, Nitrofurantoin 73.80\%, Gentamycin 66.88\%, Ciprofloxacin $\mathbf{4 1 . 4 8 \%}$, Doxycycline $\mathbf{3 6 . 3 0} \%$, Ceftazidime $\mathbf{3 4 . 5 0 \%}$, Ceftriaxone $33.62 \%$, Cefexime $31.0 \%$, Cotrimoxazole 32.31\%, Nalidixic acid 24.01\%, Cephradine 17.47\% and Ampicillin 11.35\%.
\end{abstract}

Keywords: Urinary tract infection, E.coli, antibiotic sensitivity.

\section{Introduction:}

Infection of urinary tract characterized by bacteuria, dysuria and increased frequency of micturation. UTI is the most common bacterial Infection of different age groups and both sexes. ${ }^{1}$ E.coli and Klebsiella spp., Staph. saprophyticus are the most common organisms for UTI and UTI is encountered by clinicians in developing countries. ${ }^{2}$ It is very necessary to identify uropathogens and their sensitivity pattern as early as possibly to avoid any long term complications, to reduce the risk of morbidity and proper treatment.

Unrecongnized urinary tract infection may progress into renal damage, hypertension and any stage of renal diseases. ${ }^{3}$ Misdiagnosis, delay in diagnosis and treatment of UTI appears to cause renal scaring may produce end stage of renal disease. ${ }^{4}$

The presence of microorganisms $10^{5}$ or $>10^{5} \mathrm{CFU} / \mathrm{ml}$ of urine with or without symptoms was considered as significant bacteriuria. All the microorganisms were identified by their colony morphology, staining character, pigment production, motility and other biochemical tests. ${ }^{6}$ All bacterial isolates were tested for antimicrobial susceptibility by disc diffusion method using Mueller Hinton agar media against different antimicrobial agents. ${ }^{7}$

\section{Materials and Methods:}

The prospective study was carried out in the Department of Microbiology, Dhaka National Medical College \& Hospital, Dhaka, Bangladesh, from January 2010 to December, 2010. A total of 1874 urine samples were collected from suspected cases of urinary tract infection from in-patient and outpatient department of Dhaka National Medical College \& Hospital. Samples were collected from both sexes and different age groups by clean catch mi-stream method.

Data were analyzed by Statistical Package for Social Science (SPSS). All urine samples were inoculated in Blood agar and MacConkey agar media. All plates were incubated at $37^{\circ} \mathrm{C}$ aerobically for 24 hours. After incubation plates were checked for presence of suspected pathogens. Colony was counted by calibrated loop method. ${ }^{5}$

\section{Results}

A total of 1874 urine samples were collected from patients suspected to have urinary tract infections. From the 1874 samples, 290(15.48\%) were isolated (Table-I).

Table-I: Distribution of samples of the study

\begin{tabular}{ccc}
\hline Sample & $\begin{array}{c}\text { Number of tested } \\
\text { samples studied }\end{array}$ & $\begin{array}{c}\text { Number of } \\
\text { isolated } \\
\text { bacteria }\end{array}$ \\
\hline Urine & 1874 & $290(15.48 \%)$ \\
\hline
\end{tabular}


J. Dhaka National Med. Coll. Hos. 2012; 18 (01): 4-6

Table-II: Sex distribution of patient whose urine samples yielded growth.

\begin{tabular}{|c|c|c|}
\hline Sample & $\begin{array}{c}\text { Number of } \\
\text { tested samples } \\
\text { studied }\end{array}$ & $\begin{array}{c}\text { Number of } \\
\text { isolated } \\
\text { bacteria }\end{array}$ \\
\hline Male & 291 & $36(12.38 \%)$ \\
\hline Female & 1583 & $254(16.5 \%)$ \\
\hline
\end{tabular}

Table-III: Distribution of isolated bacteria in urine samples $(\mathbf{n}=\mathbf{2 9 0})$

\begin{tabular}{|l|c|}
\hline Isolated bacteria & $\begin{array}{l}\text { Number } \\
\text { organisms (\%) }\end{array}$ \\
\hline E.coli & $229(78.97 \%)$ \\
\hline Staph. saphrophyticus & $15(5.18 \%)$ \\
\hline Coliform & $12(4.13 \%)$ \\
\hline KLebsiella spp. & $10(3.44 \%)$ \\
\hline Enterococous & $10(3.44 \%)$ \\
\hline Staph. aureus & $05(1.72 \%)$ \\
\hline Streptococcus & $05(1.72 \%)$ \\
\hline Pseudomonas spp. & $04(1.38 \%)$ \\
\hline
\end{tabular}

Among the isolates, 229(78.97\%) were E. coli, 15(5.18\%) were Staph. Saphrophyticus, 12(4.13\%) were Coliform, 10(3.44\%) were KLebsiella spp., 10(3.44\%) were Enterococous, 05(1.72\%) were Staph. aureus, 05(1.72\%) were Streptococcus and 04(1.38\%) were Pseudomonas spp. (Table-III).

Table-IV: Sensitivity pattern of E. coli and Staph. saprophyticus to different antimicrobial drugs

\begin{tabular}{|l|c|c|c|c|}
\hline \multirow{2}{*}{$\begin{array}{c}\text { Antimicrobial } \\
\text { drugs }\end{array}$} & \multicolumn{2}{|c|}{$\begin{array}{c}\text { E.coli } \\
\text { N=229) }\end{array}$} & \multicolumn{2}{c|}{$\begin{array}{c}\text { Staph. saprophyticus } \\
(\text { n=15) }\end{array}$} \\
\cline { 2 - 5 } & Sensitive & Resistant & Sensitive & Resistant \\
\hline Ampicillin & $26(11.35 \%)$ & $203(88.65 \%)$ & $8(53.33 \%)$ & $7(46.67 \%)$ \\
\hline Cephradine & $40(17.47 \%)$ & $189(82.55 \%)$ & $6(40.0 \%)$ & $9(60.0 \%)$ \\
\hline Ceftriaxone & $77(33.62 \%)$ & $152(66.38 \%)$ & $11(73.33 \%)$ & $4(26.67 \%)$ \\
\hline Cotrimoxazole & $74(32.31 \%)$ & $155(67.69 \%)$ & $5(33.33 \%)$ & $10(66.67 \%)$ \\
\hline Ciprofloxacin & $95(41.48 \%)$ & $134(58.52 \%)$ & $9(60.0 \%)$ & $6(40.0 \%)$ \\
\hline Cefuroxime & $71(31 \%)$ & $158(69.0 \%)$ & $10(66.67 \%)$ & $5(33.33 \%)$ \\
\hline Ceftazidime & $79(34.50 \%)$ & $150(65.50 \%)$ & $6(40.0 \%)$ & $9(60.0 \%)$ \\
\hline Doxycycline & $61(36.30 \%)$ & $168(63.70 \%)$ & $5(33.33 \%)$ & $11(73.33 \%)$ \\
\hline Gentamycin & $152(66.88 \%)$ & $77(33.62 \%)$ & $14(93.33 \%)$ & $1(6.67 \%)$ \\
\hline Nalidixic acid & $55(24.01 \%)$ & $174(75.99 \%)$ & $4(26.67 \%)$ & $11(73.33 \%)$ \\
\hline Nitrofurantoin & $169(73.80 \%)$ & $60(26.20 \%)$ & $11(73.33 \%)$ & $4(26.67 \%)$ \\
\hline Amikacin & $191(83.41 \%)$ & $38(16.59 \%)$ & $12(80.0 \%)$ & $3(20.0 \%)$ \\
\hline Imipenem & $193(84.28 \%)$ & $36(15.72 \%)$ & $14(93.33 \%)$ & $1(6.67 \%)$ \\
\hline
\end{tabular}

From Table-IV E.coli showed high degrees of sensitive to Imipenem (84.28\%), Amikacin (83.41\%), Nitrofurantoin $(73.80 \%)$ and Gentamicin (66.88\%) respectively and resistance to Ampicillin (88.65\%), Cephradine (82.53\%) and Nalidixic acid (75.99\%) respectively. On the other hand Staph. saprophyticus showed high degrees of sensitive to Imipenem (93.33\%), Gentamicin (93.33\%), Amikacin $(80.0 \%)$ and Nitrofurantoin $(73.33 \%)$ respectively and resistance to Nalidixic acid $(73.33 \%)$, Doxycycline (66.67\%), Ceftiaxone (66.67\%) and Cephradine (60.0\%) respectively.
Table-V: Sensitivity pattern of Klebseilla spp. And Enterococcus spp. to different antimicrobial drugs

\begin{tabular}{|l|c|c|c|c|}
\hline \multirow{2}{*}{$\begin{array}{c}\text { Antimicrobial } \\
\text { drugs }\end{array}$} & \multicolumn{2}{|c|}{$\begin{array}{c}\text { Klebsiella spp. } \\
\text { (N=10) }\end{array}$} & \multicolumn{2}{c|}{$\begin{array}{c}\text { Enterococcus spp. } \\
(\text { n=10) }\end{array}$} \\
\cline { 2 - 5 } & Sensitive & Resistant & Sensitive & Resistant \\
\hline Ampicillin & $1(10.0 \%)$ & $9(90.0 \%)$ & $4(40.0 \%)$ & $6(60.0 \%)$ \\
\hline Cephradine & $2(20.0 \%)$ & $8(80.0 \%)$ & $4(40.0 \%)$ & $6(60.0 \%)$ \\
\hline Ceftriaxone & $4(40.0 \%)$ & $6(60.0 \%)$ & $7(70.0 \%)$ & $3(30.0 \%)$ \\
\hline Cotrimoxazole & $4(40.0 \%)$ & $6(60.0 \%)$ & $3(30.0 \%)$ & $7(70.0 \%)$ \\
\hline Ciprofloxacin & $5(50.0 \%)$ & $5(50.0 \%)$ & $7(70.0 \%)$ & $3(30.0 \%)$ \\
\hline Cefuroxime & $5(50.0 \%)$ & $5(50.0 \%)$ & $3(30.0 \%)$ & $7(70.0 \%)$ \\
\hline Ceftazidime & $4(40.0 \%)$ & $6(60.0 \%)$ & $5(50.0 \%)$ & $5(50.0 \%)$ \\
\hline Doxycycline & $3(30.0 \%)$ & $7(70.0 \%)$ & $4(40.0 \%)$ & $6(60.0 \%)$ \\
\hline Gentamycin & $7(70.0 \%)$ & $3(30.0 \%)$ & $6(60.0 \%)$ & $4(40.0 \%)$ \\
\hline Nalidixic acid & $3(30.0 \%)$ & $7(70.0 \%)$ & $2(20.0 \%)$ & $8(80.0 \%)$ \\
\hline Nitrofurantoin & $5(50.0 \%)$ & $5(50.0 \%)$ & $6(60.0 \%)$ & $8(40.0 \%)$ \\
\hline Amikacin & $9(90.0 \%)$ & $1(10.0 \%)$ & $7(70.0 \%)$ & $3(30.0 \%)$ \\
\hline Imipenem & $10(100.0 \%)$ & $0(00 \%)$ & $7(70.0 \%)$ & $3(30.0 \%)$ \\
\hline Erythromycin & - & - & $6(60.0 \%)$ & $4(40.0 \%)$ \\
\hline Linazolid & - & - & $6(60.0 \%)$ & $4(40.0 \%)$ \\
\hline Vancomycin & - & - & $7(70.0 \%)$ & $3(30.0 \%)$ \\
\hline
\end{tabular}

From Table-V Klebsiella spp. showed high degrees of sensitive to Imipenem (100.0\%), Amikacin (90.0\%) and Gentamicin (70.0\%) and resistance to Ampicillin (90.0\%), Cephradine (80.0\%), Doxycycline (70.0\%) and Nalidixic acid $(70.0 \%)$ respectively. On the contrary, Enterococcus spp. showed high sensitive to Vancomycin (70.0\%), Imipenem (70.0\%), Amikacin (70.0\%), Ceftriaxone (70.0\%) and Ciprofloxacin (70.0\%) and high resistance to Nalidixic acid (80.0\%), Cotrimoxazole (70.0\%) and Cefuroxime (70.0) respectively.

\section{Discussion:}

The presence of infection in the urinary tract indicates urinary tract infections. ${ }^{8}$ Identification of uropathogens and their sensitivity pattern are very important for early treatment of urinary tract infections. In the present study, the most common isolated uropathogens were E.col 229(78.97\%), Staph. saphrophyticus 15(5.18\%), Coliform 12(4.13\%), KLebsiella spp. 10(3.44\%), Enterococous 10(3.44\%), Staph. aureus 05(1.72\%), Streptococcus 05(1.72\%) and Pseudomonas spp 04(1.38\%) respectively. E.coli is the most common uropathogens in both sexes and different age groups. This finding is similar to studies done in Tunisia. ${ }^{9}$ Antibiotic sensitivity pattern varies from one country to another depending on antibiotic use.

In our study among the E.coli strains, 193(84.28\%) were sensitive to Imipenem, 191(83.41\%) to Amikacin, $169(73.80 \%)$ to Nitrofurantoin and 152(66.88\%) to Gentamycin. Among the Staph. saprophyticus, 14(93.33\%) were sensitive to Imipenem, $14(93.33 \%)$ to Gentamycin, $12(80.0 \%)$ to Amikacin, and 11(73.33\%) to Nitrofurantoin.

Among the Klebsiella spp. 10(100\%) were sensitive to Imipenem, 9(90\%) to Amikacin and 7(70\%) to Gentamycin.

Among the Enterococcus spp. 7(70\%) were sensitive to Vancomycin, 7(70\%) to Imipenem, Amikacin 7(70\%) and $7(70 \%)$ Ciprofloxacin. On the other hand the results of this study showed that sensitivity rates of the uropathogens were low for Ampicillin, Cephradine and Cotrimoxazole. The 
J. Dhaka National Med. Coll. Hos. 2012; 18 (01): 4-6 lower rate of sensitive might be due to indiscriminate and widespread use of antibiotics in our country.

A study at Turkey observed that the resistance rate of Ampicillin is high followed by Cephradine and Cotrimoxazole. ${ }^{10}$

\section{Conclusion:}

Urinary tract infection is the most common disease occurs in both sexes and different age groups. The common uropathogens are E.coli followed by Staph. saprophyticus and Klebsiella spp. So early identification of uropathogens and knowledge of sensitivity pattern of bacterial strains with help to guide the appropriate and judicious antibiotic use.

\section{References:}

1. Round AR, Puttulo MS. The natural history of urinary in adult. Med Clin North Am. 1991; 75: 299-312.

2. Tessema B, Kassu A, Mulu A and Yismaw G. Predominant isolates of urinary tract pathogens and their antimicrobial susceptibility pattern in Gondar. University Teaching Hospital, Northwest Ethiopia. Ethiop Med J. 2007; 1: 61-70.
3. Adjei $\mathrm{O}$ and Opoku CH. Urinary tract infection in African infants. International Journal of Antimicrobial Agents. 2004; 3: 32-34.

4. Jones RN, Juler KC, Pfaller MA, and Winkur PL. Characteristics of pathogens causing urinary tract infections in hospitals in North America. Results from the Sentry Antimicrobial surveillance program. Diagnosis Microbial Infection Disease. 1999; 35: 55-63.

5. Hoeprich PD. Culture of the urine journal lab and clinical medicine. 1960; 56(6): 899-906.

6. Cheesbrough M. District laboratory practice in tropical countries. ELBS, Cambridgeshire, England. 2000; 2: 175-80.

7. Baur AW, Kibry WMM, Sherris JC and Turck M. Antibiotic susceptibility testing by a standardized single disc method. The Am J Clin Pathol. 1966; 36: 493-96.

8. Jonathan and Evan. Investigation of urinary tract infection in children. Current Paediatrics. 2006; 16: 248-5.

9. Ghedria L, Messaoudi A, Ben Meriem C and Guedich MM. Profile of antimicrobial resistance of agents causing urinary tract infection in children. Tunis Med J. 2007; 82: 299-305.

10. Yuksel S, Ozturk B and Kavaz A. Antibiotic resistance of urinary tract pathogens and evaluation of empirical treatment in Turkish children with urinary tract infections. Int. $J$ Antimicrob Agents. 2006; 28: 423-460.

11. Kumar P. and Clark M. Clinical Medicine $7^{\text {th }}$ edition 2009:602. 